\title{
Opsoclonus-Myoclonus syndrome
}

\author{
Marta Esteves Guedes, Ana Catarina Almeida, Maria Sara Patricio, João Marques Costa
}

Ophthalmology Department, Hospital Egas Moniz, Lisbon, Portugal

Correspondence to Dr Marta Esteves Guedes, marta.ce.guedes@gmail.com

\section{DESCRIPTION}

Opsoclonus-Myoclonus syndrome is a rare dyskinesia due to an underlying infectious, metabolic or neoplastic process. ${ }^{1}$ It is frequently caused by neuroblastoma in children and breast or lung carcinoma in adults. It is characterised by high amplitude, multidirectional, arrhythmic and conjugate ocular saccadic intrusions without intersaccadic latency causing oscillopsia ${ }^{2}$ and it is associated with myoclonus of axial and/or apendicular musculature $^{3}$ and ataxia. Autoimmune dysfunction of Purkinje cells in the dorsal vermis and subsequent disinhibition of oculomotor fastigial region seems to be the most probable mechanism. ${ }^{4}$ A 53-year-old female, diagnosed with breast carcinoma $2 \frac{1}{2}$ years before the first ophthalmologic assessment. She had refused mastectomy and had nausea, vomiting and cerebellar gait ataxia followed by dysarthria, opsoclonus-related oscillopsia (could not read) and cervical myoclonus. The syndrome was exacerbated by tactile, sound or bright light stimuli and reduced by convergence (video 1). The patient was submitted to left radical mastectomy and monthly chemotherapy (adriamicin $60 \mathrm{mg} / \mathrm{m}^{2}$ and ciclophosphamide $600 \mathrm{mg} / \mathrm{m}^{2}$ ). Due to persistence of the opsoclonus-myoclonus syndrome with severe gait ataxia, intravenous immunoglobulin (IVIG), 2 $\mathrm{g} / \mathrm{kg}$, was started. Progressive improvement of oscillopsia and complete remission of opsoclonus was evident. Six months after initiating therapy, she had complete remission of the myoclonic component. Mild broad base gait is at the moment, possible without aid. We report a severe Opsoclonus-Myoclonus syndrome starting 21/2 years after breast carcinoma. Mastectomy and adjuvant chemotherapy were essential in stabilising the underlying pathologic mechanism but the immune-modulating action of IVIG seems to be helpful since clinical improvement was observed after initiating therapy with complete remission after 6 months.

Video 1 Opsoclonus-Myoclonus video: high amplitude multidirectional and irregular saccadic intrusions, without interssaccadic latency, exacerbated by bright light stimuli and reduced by convergence. Vestibulo-ocular reflex and opto-kinetic nystagmus are present. We can see concomitant cervical axial musculature myoclonus.10.1136/bcr.09.2011.4834v1

Competing interests None.

Patient consent Obtained

\section{REFERENCES}

1. Bataller L, Graus F, Saiz A, et al. Clinical outcome in adult onset idiopathic or paraneoplastic opsoclonus-myoclonus. Brain 2001;124(Pt 2):437-43.

2. Leigh RJ, Zee DS, eds. The Neurology of Eye Movements. Third edition. New York: Oxford University Press 1999.

3. Caviness JN, Forsyth PA, Layton DD, et al. The movement disorder of adult opsoclonus. Mov Disord 1995;10:22-7.

4. Pranzantelli MR. The neurobiology of the opsoclonus-myoclonus syndrome. Clin Neuropharmacol 1992;15:186-228.

This pdf has been created automatically from the final edited text and images.

Copyright 2011 BMJ Publishing Group. All rights reserved. For permission to reuse any of this content visit http://group.bmj.com/group/rights-licensing/permissions.

BMJ Case Report Fellows may re-use this article for personal use and teaching without any further permission.

Please cite this article as follows (you will need to access the article online to obtain the date of publication).

Guedes ME, Almeida AC, Patricio MS, Costa JM. Opsoclonus-Myoclonus syndrome. BMJ Case Reports 2011;10.1136/bcr.09.2011.4834, date of publication

Become a Fellow of BMJ Case Reports today and you can:

- Submit as many cases as you like

- Enjoy fast sympathetic peer review and rapid publication of accepted articles

- Access all the published articles

- Re-use any of the published material for personal use and teaching without further permission

For information on Institutional Fellowships contact consortiasales@bmjgroup.com

Visit casereports.bmj.com for more articles like this and to become a Fellow 